\title{
Europe's Building Stock and Its Energy Demand: A Comparison Between Austria and Italy
}

\author{
Simon Pezzutto, Franziska Haas, Dagmar Exner \\ and Stefano Zambotti
}

\begin{abstract}
The building sector is responsible for approximately $40 \%$ of the European Union's total primary energy demand, which is mainly attributed to space heating, cooling and domestic hot water. In 2010, its value reached $1800 \mathrm{Mtoe} / \mathrm{y}$, to which buildings contributed $720 \mathrm{Mtoe} / \mathrm{y}$. While the Austrian and Italian building stocks are well investigated (e.g., classified by different building typologies, existing floor area, ownership etc.), there still is a lack of information concerning energy/demand values for space heating, cooling and domestic hot water per the various construction periods. In order to identify differences in energy demand, we first classified residential and service sector buildings in Austria and Italy and then attributed specific demand values in $\mathrm{kWh} / \mathrm{m}^{2}$ year. We further subdivided existing buildings per construction period: buildings (i) constructed before 1945, (ii) erected after World War II and before 1960, (iii) built between 1960 and 1980, (iv) constructed during 1980-1990 and 1990-2000, (v) dating to 20002010, and erected after 2010. The investigated buildings in the residential sector comprise: single-family houses, multi-family houses and apartment blocks (>eight floors); and in the service sector: offices solely. We concentrated our service-sector research on offices motivated by their highest space-cooling-demand ratio within the whole European building stock. The main results show that Austria and Italy share a certain homogeneity among building typologies, construction methodologies, portions of built-floor area per construction span, and specific energy demands per construction period.
\end{abstract}

Keywords Building stock · Europe $\cdot$ Energy demand $\cdot$ Austria $\cdot$ Italy

The original version of this chapter was revised: Open Access under a CC BY 4.0 license has been newly included. The erratum to this chapter is available at https://doi.org/10.1007/978-3319-75774-2_47

\footnotetext{
S. Pezzutto $(\bowtie) \cdot$ S. Zambotti

Urban and Regional Energy Systems, Institute for Renewable Energy,

European Academy of Bolzano (EURAC Research), Bolzano, Italy

e-mail: simon.pezzutto@eurac.edu

F. Haas · D. Exner

Energy Retrofit of Historic Buildings, Institute for Renewable Energy,

European Academy of Bolzano (EURAC Research), Bolzano, Italy
}

(C) The Author(s) 2018

A. Bisello et al. (eds.), Smart and Sustainable Planning for Cities and Regions,

Green Energy and Technology, https://doi.org/10.1007/978-3-319-75774-2_3 


\section{Introduction}

The EU is aiming to decrease greenhouse gas (GHG) emissions by $20 \%$ by 2020 with respect to 1990s' levels. In parallel, renewable-energy sources (RES) production is expected to increase by $20 \%$, along with a $20 \%$ overall efficiency upgrade (EC 2017a).

By 2030 an integrated policy framework will compel EU Member States (MS) to direct a coordinated approach and to provide investors with sound regulatory guidelines. By that year, the EU intends to decrease domestic emissions of GHG by $40 \%$ relative to 1990 levels. National policies are designed to permanently improve energy efficiency and aim to increase the energy produced with RES to $27 \%$ (EC 2017b).

In order to achieve the 2050 targets, the EU must pursue further efforts. The EU MS have declared a goal of decreasing GHG emissions in Europe by $80-95 \%$, relative to 1990 levels by 2050 (EC 2017c).

EU's 2010 primary-energy demand amounted to about $1800 \mathrm{Mtoe} / \mathrm{y}$, principally attributable to various heating and cooling applications (almost 900 Mtoe/y, accounting also for industrial heat), followed by transportation and electricityabout 540 and 360 Mtoe/y respectively (Pezzutto 2014). Of the total, buildings account for around 720 Mtoe/y (40\% of the entire EU primary-energy demand). The largest shares of energy demand within the European building stock are assigned, in decreasing order, to space heating (SH), domestic hot water (DHW) and space cooling (SC) with respectively around 2900, 400 and $200 \mathrm{TWh} / \mathrm{y}$ (Pezzutto et al. 2015).

Recently, the EU and all its MS conducted a thorough investigation aimed at classifying their building stocks based on building typologies, existing floor area, ownership etc. (EC 2017d), without however specifying energy- demand values for $\mathrm{SH}, \mathrm{SC}$ and DHW according to the various construction periods.

A proper investigation aimed at determining these specific values is still lacking. The majority of energy-demand data is related to earlier investigations, such as: the Intelligent Energy Europe (IEE) project TABULA-Typology Approach for Building Stock Energy Assessment (TABULA 2017), the BPIE Data Hub for Energy Performance of Buildings (BPIE 2017) and confidential data kindly provided by the Vienna University of Technology (Invert/EE-Lab 2015).

Further relevant sources of information to explore Austria's and Italy's building stock are national statistical offices - Statistik Austria and ISTAT-Istituto nazionale di statistica (Statistik Austria 2017; ISTAT 2017).

The main obstacles encountered in our study relate to the erroneous interchange of the concepts regarding energy demand and energy consumption and the scarce availability of space-cooling data. In addition, there is only isolated information on the energy demand of the historic non-residential building stock.

Section 2 details information collection and analysis methodologies. Section 3 presents the outcomes for Austria and Italy, and discussion and conclusions are provided in Sect. 4. 


\section{Methodology}

Data per construction periods in millions of square meters $\left(\mathrm{Mm}^{2}\right)$ and specific demands for $\mathrm{SH}, \mathrm{SC}$ and $\mathrm{DHW}\left(\mathrm{kWh} / \mathrm{m}^{2}\right.$ year) were collected separately for Austria and Italy and sorted by the household and service sectors, addressing specific subsectors such as single-family houses (SFHs), multi-family houses (MFHs) and apartment blocks (ABs-buildings characterized by $>8$ floors). We concentrated our service-sector research only on offices motivated by their highest SC demand ratio within the entire European building stock (Pezzutto 2014).

Concerning the collected information, it is important to distinguish between energy demand and consumption.

Demand represents the net energy required to cover SH and SC needs; consumption is the energy input at the devices required to satisfy the demand. The two quantities thus differ by disparate conversion factors (Capehart 2007). In dealing with SH and DHW, since the efficiency of boilers is < one (0.8-0.9 for currently installed technologies in Europe), energy consumption is higher than demand.

An energy-efficiency ratio (EER) greater than one for electrically driven SC equipment (around two-three for currently installed technologies within the EU) causes air-conditioning (AC) energy consumption to be lower than demand (Recknagel et al. 2010). We wish to stress that, while it is correct to compare SH and SC demand, electricity consumption (in heat pumps and air-conditioners) can only be fairly compared to fuel consumption (e.g., gas in a gas boiler) by performing an adequate conversion to primary energy. Indeed, the two energy carriers have a different content of grey energy when employed in the final consumption. Primary energy (usually expressed in terms $\mathrm{kWh}$ or toe) accounts in fact for the consumption of fossil resources providing a basis for a clear comparison among various different energy carriers (Pezzutto 2014).

In order to present a complete picture of the Austrian and Italian building stocks and to describe time-related specifications, we proceeded on the basis of the following breakdown:

(i) Buildings constructed before 1945 are generally classified as historic buildings. The historic-building stock is highly inhomogeneous, making it difficult to make a standardized assessment. Nevertheless, certain characteristics may still be generalized, such as the massive construction for historic residential buildings;

(ii) Buildings erected after World War II and before 1960 - the building-industry boom - are generally characterized by poor insulation and inefficient energy systems (caused by the choice of cheap construction materials and short building times) resulting in a higher specific energy demand;

(iii) Buildings built between 1961 and 1980 present the first insulation applications (as a consequence of the world energy crises of the 1970s);

(iv) Buildings built during 1981-1990 and 1991-2000 reflect the introduction of thermal protection ordinances (around 1990); 
(v) Buildings dating to 2001-2010 are considered to assess the impact of the European Performance of Buildings Directive (2002/91/EC and following recasts);

(vi) Buildings constructed after 2010 are analyzed to understand the impact of the economic crisis on Europe's construction branch.

Data quality, completeness, accuracy, and reliability proved to be very important aspects in the process of establishing the database for this investigation. Among others, the following main points have been taken into consideration: (i) Data inventory, (ii) Data reliability and (iii) Data definition and comparability:

(i) Data inventory

One of the major challenges in developing an inventory of data for building-stock analysis is to provide a complete list of all existing information. Unfortunately, the data provided are never fully complete. The authors therefore collected data from national statistics to increase data coverage and availability.

Filling in the data gaps implied not only extrapolating and assembling data from large data tools available online (e.g., IEE TABULA, BPIE Data Hub for Energy Performance of Buildings, Statistik Austria, ISTAT etc.), but also researching data source-by-source from single scientific literature fonts such as journal papers, conference proceedings and project deliverables.

One important aspect of the data inventory is to ensure that the information can be understood and interpreted correctly. The data provide standardized structured information explaining origin, creator, and a time reference.

(ii) Data reliability

The present analysis has been carried out after consulting a few dozen peer-reviewed papers and over ten databases (of which only a small part has been included in the present list of references due to the sources' lack of reliability). All sources have been analyzed assessing data reliability and complementing missing gaps by in-depth investigations.

(iii) Data definition and comparability

The use of standardized formats and units by most data providers doesn't imply that data are necessarily fully comparable. Adjusting differences and inconsistencies among different measures, assumptions, methods, time references and specifications to improve data comparability is one of the most important aspects of the whole process of data elaboration.

Data has been collected for each country with reference to the most recent year.

Next coming Figs. 1 and 3 of the results section are based on data retrieved with a unit of $\mathrm{Mm}^{2}$. The percentages indicated are based on the respective floor areas. In contrast, portions shown in Figs. 2, 4, 5 and 6 are based on the number of buildings erected.

In the case of Figs. 8 and 10, no reliable values could be found concerning the historic-building stock, and therefore this part of the indicated charts are empty. The same applies for the case of Italy with regard to Figs. 4 and 6. 

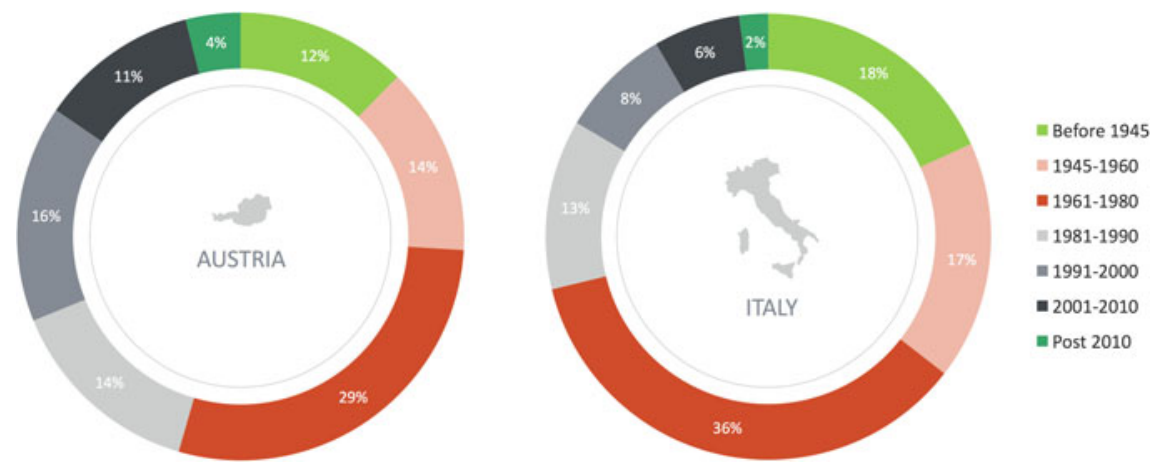

Fig. 1 Subdivision of the Austrian and Italian residential building stock raised per construction period (Before 1945-Post 2010) —\% (Amtmann and Altmann-Mavaddat 2014; Statistik Austria 2017; Norris and Shiels 2004; Hartl 2010; ISTAT 2017; Invert/EE-Lab 2017)
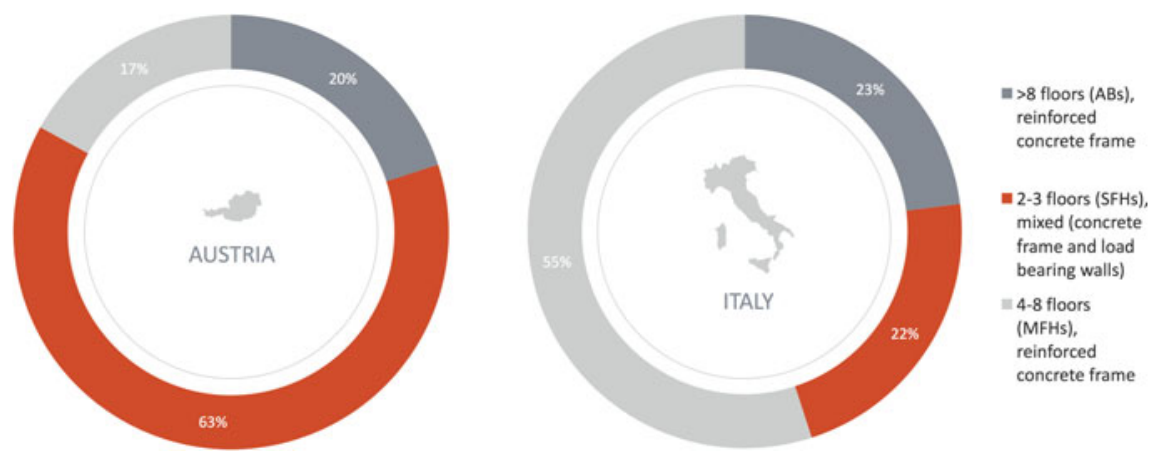

Fig. 2 Subdivision of the Austrian and Italian residential building stock per different building types-\% (Baulicher Brandschutz 2008; Demuth and Malloth 2006; Corrado 2012)

\section{Results}

Figure 1 compares Austria and Italy with regard to the residential building stock erected per construction period (Before 1945-Post 2010) in percentages.

These two figures show that both countries have a peak in built construction during the period 1961-1980, with values around 30\%. Both in the previous and following time frames, percentages decrease, showing smallest values for Austria, as well as for Italy, in the time periods 2001-2010 and Post 2010. A number of recent investigations show this trend being present for the entire EU building stock (Economidou 2011; Meijer et al. 2009; Pezzutto 2014).

It should be noted that historic buildings are present in a much higher percentage in Italy than in Austria, i.e., 18 and 12\% respectively. The difference in the historic-building stock is the result of increased construction activity in Austria in 
the post-war period. Austria shows a double amount with respect to Italy during 1991-2000 (again with around 16 and 8\%).

Figure 2 visualizes the breakdown of various building types within the residential sector of the two countries investigated. The residential buildings analyzed are usually characterized by two-three floors in the case of SFHs, MFHs by foureight, and ABs have more than eight floors (Baulicher Brandschutz 2008; Demuth and Malloth 2006; Corrado 2012).

With regard to the construction methodology, SFHs are usually characterized by concrete frames and load bearing walls and Abs, as well as MFHs, by reinforced concrete frames (Baulicher Brandschutz 2008; Demuth and Malloth 2006; Corrado 2012).

As shown in Fig. 2, Austria and Italy significantly differ for all of the investigated aspects. Austria's residential sector is dominated by SFHs with more than $60 \%$. In contrast, SFHs are the least common building type in Italy with approximately 20\%. Next, MFHs in Austria do not reach 20\%, while in Italy these dominate the household sector with 55\%. The only similarity concerns ABs: in both countries their presence comprises around $20 \%$.

Figure 3 compares Austria and Italy with regard to the built-floor area of the office-building stock per various construction period.

As shown in Fig. 3, the majority of offices in Austria were built within the time period 1961-1980. The same situation exists concerning the residential buildings (Fig. 1). By contrast, in Italy the highest share of offices belongs to the historic-building stock, built before 1945. The percentage of offices built after World War II and before 1960 is almost twice as high for Austria for Italy, with 17 and $10 \%$ respectively. The residual construction periods show decreasing values from the 1980s until today, with one exception for Italy: during 1991-2000, fewer offices were erected than in the next construction period of 2001-2010. Moreover, it has to be highlighted that, from 2010 onwards, a significant higher percentage of offices were built in Italy compared to Austria-respective values of 9 and $2 \%$.

Figure 4 subdivides various building types within the Austrian office sector. With regard to the construction methodology, buildings with four-eight floors are
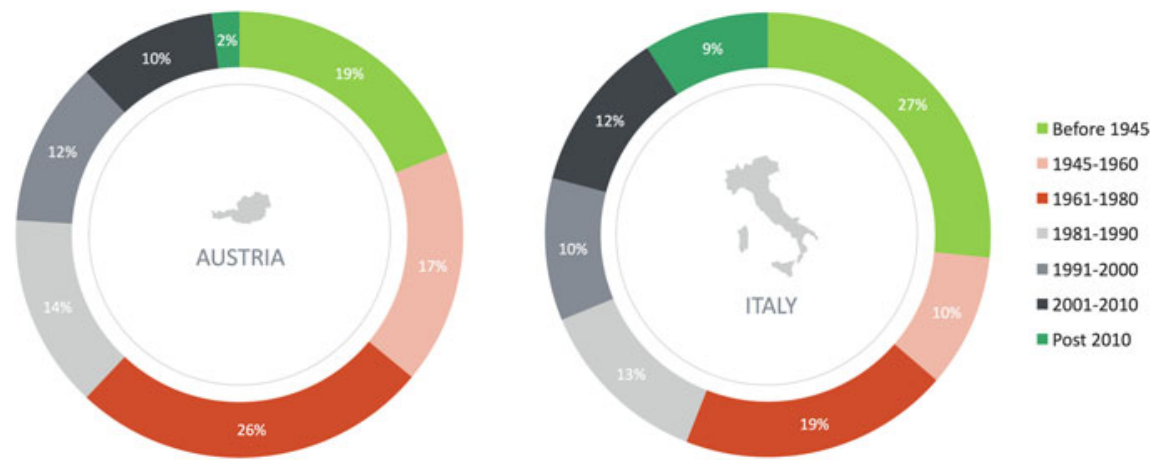

Fig. 3 Subdivision of the Austrian and Italian office building stock per construction period (Before 1945-Post 2010) —\% (Hartl 2010; Amtmann and Altmann-Mavaddat 2014; Meijer et al. 2009; Norris and Shiels 2004; ISTAT 2017; Invert/EE-Lab 2017) 
usually characterized by a reinforced concrete frame or a mix of concrete frame and load bearing walls. The same is true for office buildings with more than eight floors.

As visible in Fig. 4, the absolute majority of office buildings have between four and eight floors, with more than 60 and almost 20\%. Structures higher than eight floors are less common - a total of $18 \%$. In the case of Italy, the only information found is that the majority of office buildings are characterized by more than eight floors and reinforced concrete frames.

Figure 5 displays the ownership patterns of dwellings within both investigated countries.

As shown in Fig. 5, in both nations the absolute majority of dwellings are owner occupied. It has to be stressed that in this respect, Italy is characterized by a persistently higher value than Austria, with more than 90 and almost 60\% respectively. In fact, Italy has the highest percentage of owner-occupied dwellings within the European Union (EC 2015). The second position is held by rented dwellings and social housing for Austria and Italy, respectively. Other forms of tenure (e.g., cooperative, squatting etc.) are 3\% in Austria and 1\% in Italy. Furthermore, for Italy it was possible also to find information regarding commercial and state, region and municipality ownership. However, these cover just a small part-2 and $1 \%$, respectively.

Figure 6 visualizes the ownership pattern of Austrian offices.

As visible in Fig. 6, a parity is present between single and multiple ownership, with $41 \%$ of both. The remaining part-almost $20 \%$ - belongs to other ownership types (e.g., fractional ownership).

Figure 7 indicates the evolvement of SH and DHW demand for Austria's and Italy's household sectors within a time range spanning from before 1945 until today.

As shown in Fig. 7, the historic-building stock is characterized by a lower SH and DHW demand than for the time period 1945-1960. The difference in energy need of
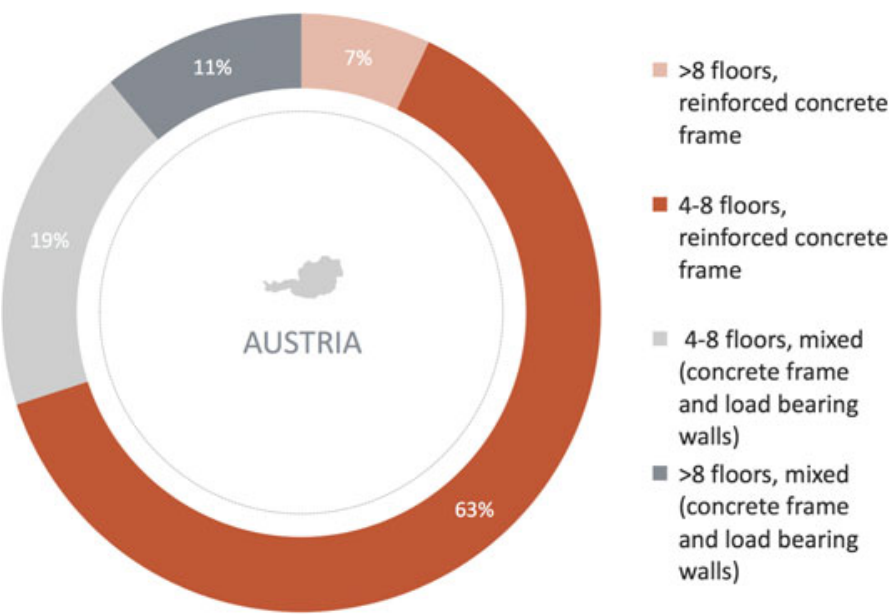

Fig. 4 Subdivision of the Austrian office-building stock per different building types — \% (Statistik Austria 2017; Cost-effective 2017) 

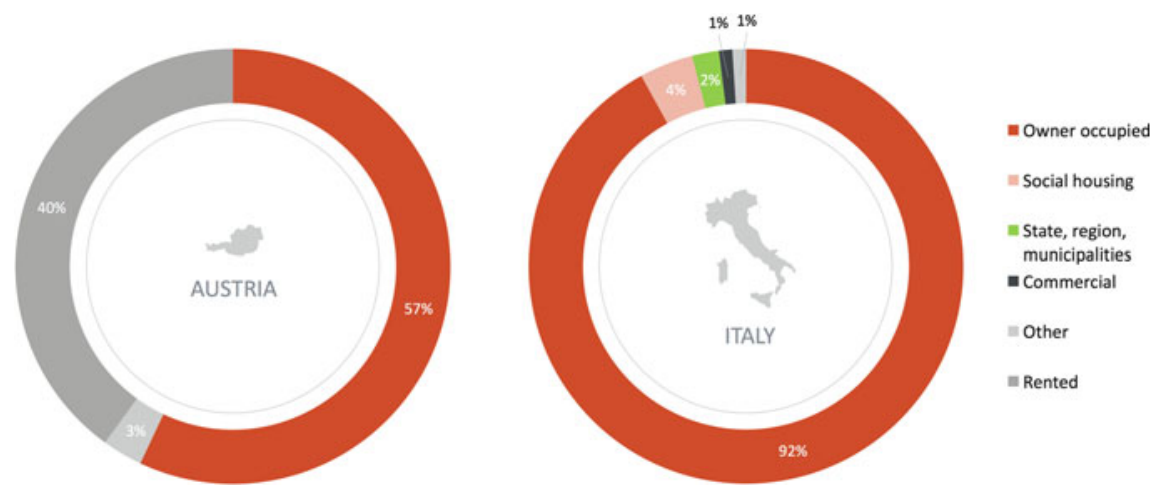

Fig. 5 Subdivision of the Austrian and Italian ownership patterns, residential sector-\%. (Norris and Shiels 2004; Melograno and Pezzutto 2010)

Fig. 6 Subdivision of the Austrian ownership structure, office sector-\% (Statistik Austria 2017)

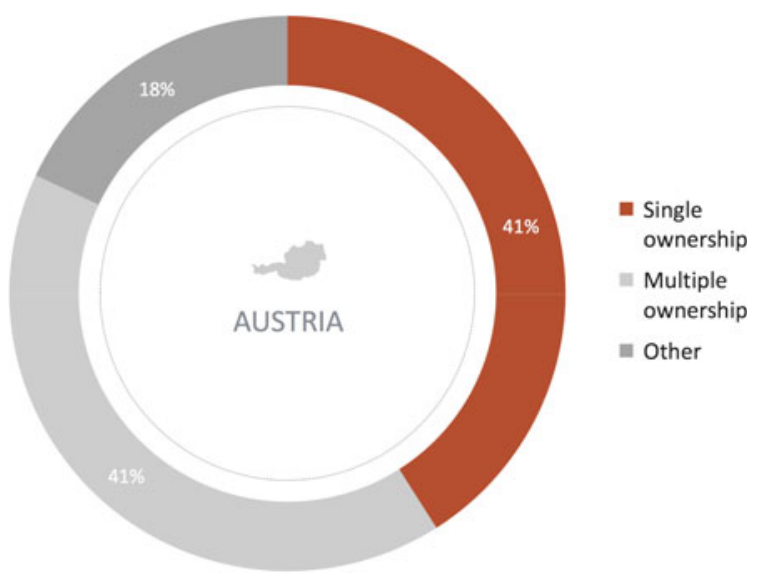

the buildings erected within the two latter time periods is considerable. In the case of Italy, we see a rise from approximately 80 to $220 \mathrm{kWh} / \mathrm{m}^{2}$ year, while in Austria an increase is seen from around 160 to almost $200 \mathrm{kWh} / \mathrm{m}^{2}$ year. The following time periods see a constant decrease for both countries from about $200 \mathrm{kWh} / \mathrm{m}^{2}$ year after World War II until $\sim 50 \mathrm{kWh} / \mathrm{m}^{2}$ year for buildings erected after 2010 . Italy shows a slightly higher energy demand than Austria's buildings for almost all time periods, with one exception: the historic-building stock.

A possible reason for Italy's higher SH and DHW demand in the period 19451960 to today is related to Austria's better and more widespread buildings insulation, as well as a more efficient use of SH and DHW technologies (TABULA 2017).

Figure 8 visualizes the evolution of SH and DHW demand for Austria's and Italy's office sector for buildings erected from World War II until today. Unfortunately, it was not possible to find data for the given graph concerning offices constructed before 1945 . 


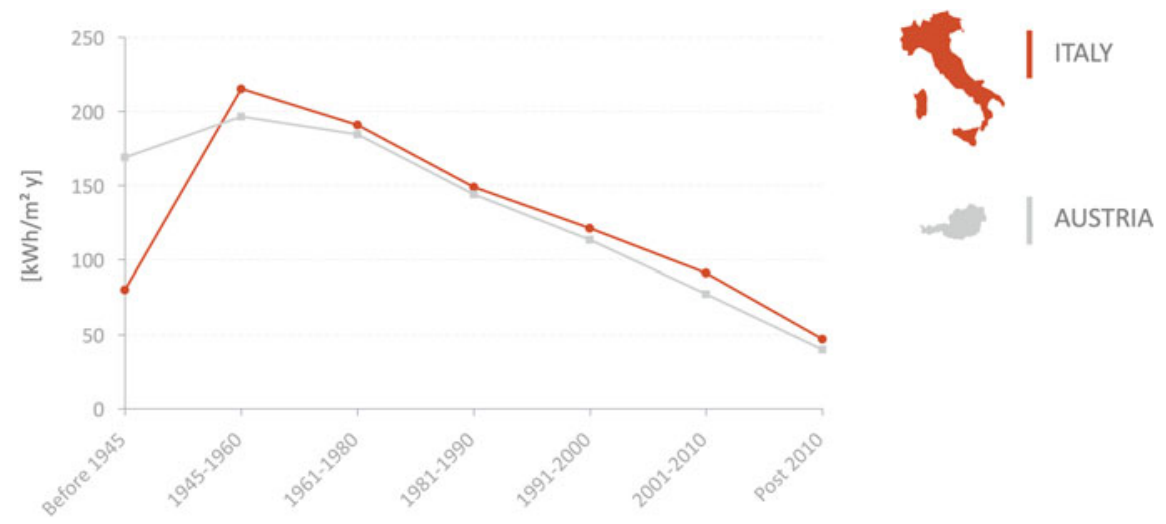

Fig. 7 Development of the space-heating and domestic hot-water demand in Austria and Italy (Before 1945-Post 2010), residential sector- $\mathrm{kWh} / \mathrm{m}^{2}$ year (Mahlknecht 2009; Lazzarin et al. 2001; Solair 2008; Energi 2002; Ostermann et al. 2010; Benejam et al. 2012; Invert/EE-Lab 2017)

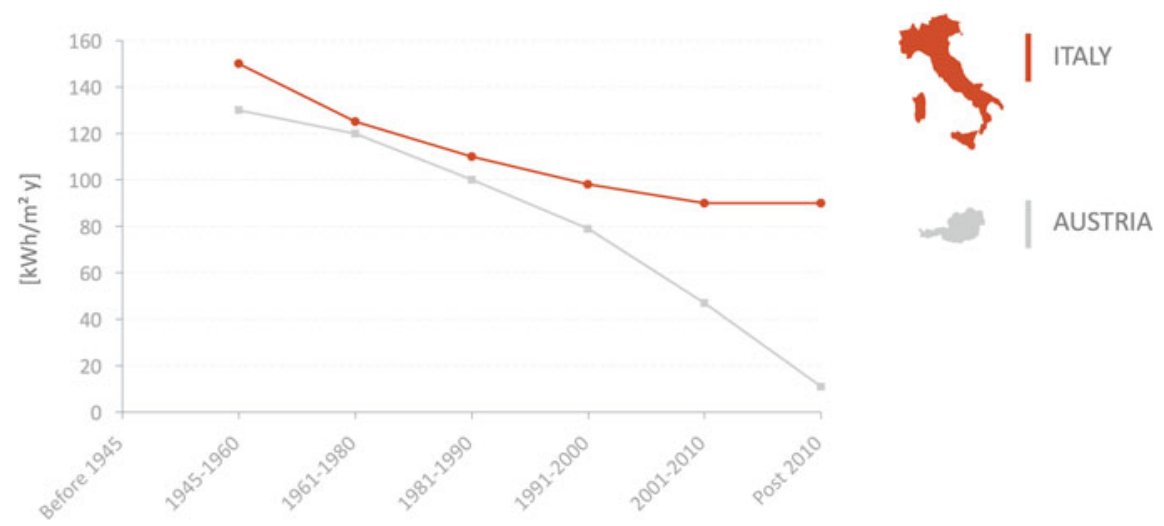

Fig. 8 Development of the space-heating and domestic hot-water demand in Austria and Italy (Before 1945-Post 2010), office sector- $\mathrm{kWh} / \mathrm{m}^{2}$ year (Mahlknecht 2009; Lazzarin et al. 2001; Solair 2008; Energi 2002; Öhlinger et al. 2010; Benejam et al. 2012; Invert/EE-Lab 2017)

As shown in Fig. 8, there is a constant decrease of SH and DHW demand from the period of 1945-1960 until 2010 and afterwards. From World War II up to today, the values for the two investigated countries differ more and more, reaching numbers of approximately 90 and $10 \mathrm{kWh} / \mathrm{m}^{2}$ year for Italy and Austria respectively in 2010 until today. Italy shows consistently higher values than Austria.

Figure 9 indicates the evolution of SC demand in both countries in the residential sector from the time period before 1945 until today.

As can be seen in Fig. 9, in both nations the SC demand is highest for buildings from the period 1945-1960. Afterwards, in both countries, the SC demand constantly decreases until today (Post 2010). Italy is characterized by a reduction in 


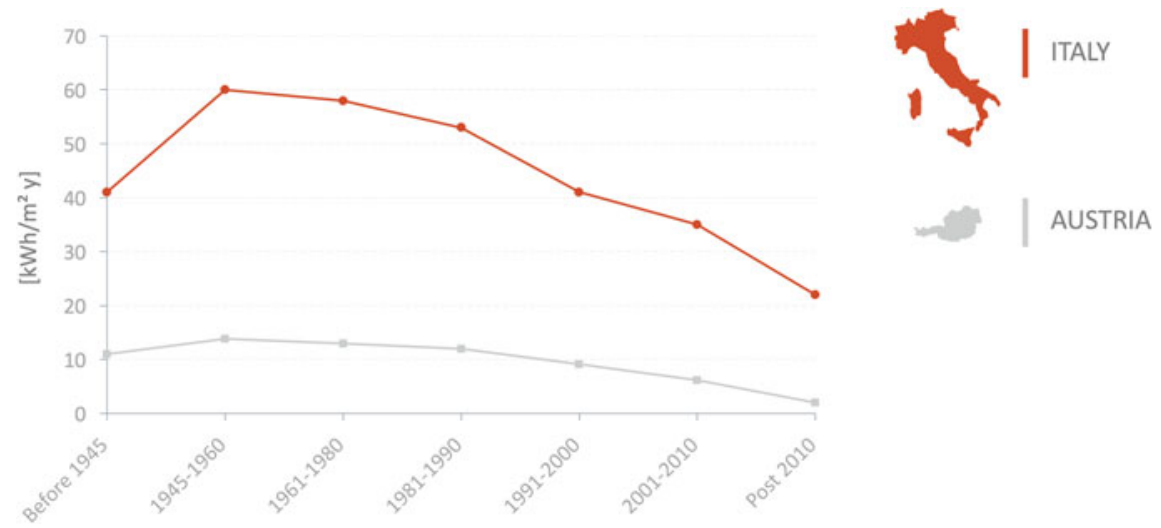

Fig. 9 Development of the space-cooling demand in Austria and Italy (Before 1945-Post 2010), residential sector $-\mathrm{kWh} / \mathrm{m}^{2}$ year (Aprile 2007; Adnot 2011)

energy demand of approximately $60-20 \mathrm{kWh} / \mathrm{m}^{2}$ year and Austria from 10 to 2 $\mathrm{kWh} / \mathrm{m}^{2}$ year. Thus, Italy has reduced its energy demand for SC by about a factor of 3 and Austria by about a factor of 5 .

Italy shows much higher values than Austria - on average, around 40 compared to $5 \mathrm{kWh} / \mathrm{m}^{2}$ year, respectively. A possible reason for the discrepancy could be warmer climatic conditions in Italy compared to Austria (Vetmeduni Vienna 2017).

Figure 10 depicts the evolution of SC demand for the two countries in offices erected before 1945 until Post 2010.

As apparent from Fig. 10, a constant decline in SC demand occurred both in Austria and in Italy from World War II until 2010 and afterwards. Italy is characterized by a reduction in energy demand of approximately 90 to $30 \mathrm{kWh} / \mathrm{m}^{2}$ year and Austria from 20 to $4 \mathrm{kWh} / \mathrm{m}^{2}$ year. Thus, as was the case for Fig. 9, Italy has reduced its energy demand for SC by about a factor of 3 and Austria by about a factor of 5 .

\section{Discussion and Conclusions}

The European Union is facing unprecedented challenges related to climate and energy aspects, with specific goals to be achieved by 2020, 2030 and 2050.

The European primary energy demand amounted to about $1800 \mathrm{Mtoe} / \mathrm{y}$ in 2010, mainly caused by various different types of heating and cooling applications (almost 900 Mtoe/y, not only related to building' space heating and cooling, but also industrial heat), followed by transportation and electricity (about 540 and 360 Mtoe/y respectively). Buildings account for about 720 Mtoe/y (40\% of the entire EU primary energy demand). The majority of energy demand within the European building stock is attributed, in decreasing order, to space heating, domestic hot-water and space-cooling purposes, with approximately 2900, 400 and 200 TWh/y respectively (Pezzutto et al. 2015). 


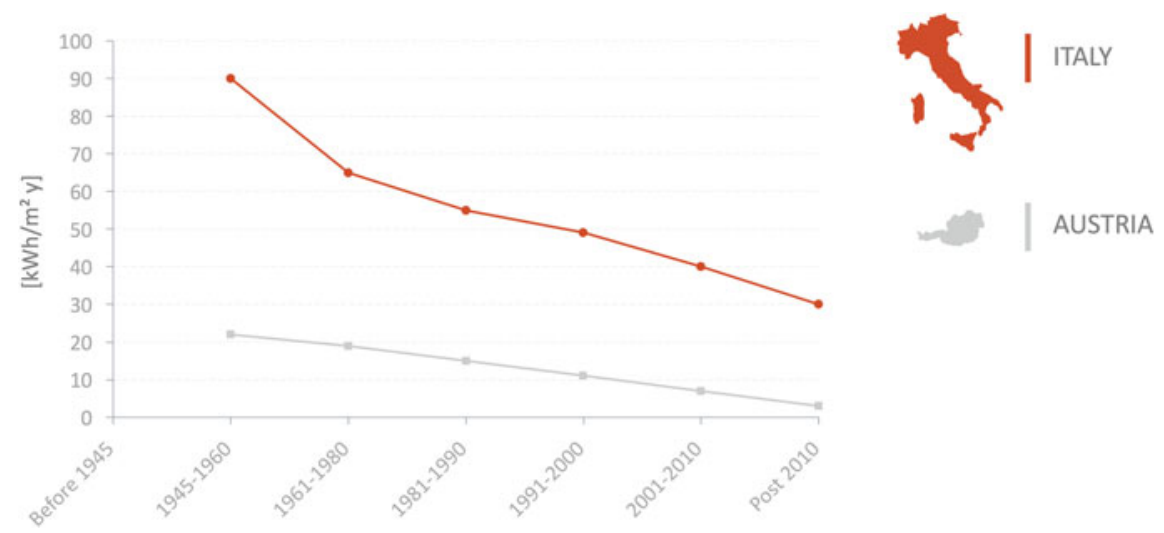

Fig. 10 Development of the space-cooling demand in Austria and Italy (Before 1945 Post 2010), office sector- $\mathrm{kWh} / \mathrm{m}^{2}$ year (Aprile 2007; Adnot 2011)

Our results show that Austria and Italy share a number of homogeneities among building typologies (in total percentage), construction methodologies, portions of built-floor area per construction span, and specific energy demands per construction period.

In fact, looking at the subdivision of the Austrian and Italian residential and service (offices) building stocks raised per construction periods (Before 1945-Post 2010)_Figs. 1 and 3-one can notice that almost all construction spans show similar values and follow the same trends.

Similarities are present also in the subdivision of the Austrian and Italian residential-building stocks per different types-Fig. 2-with regard to the proportions of sections given and respective construction methodologies.

Concerning the subdivision of the Austrian and Italian ownership patterns for the residential sector-Fig. 5- once again nearly all construction features show relatively similar values and follow the same trends.

Regarding the development of space-heating and domestic hot-water, as well as space-cooling, demands, Austria and Italy (Before 1945-Post 2010) exhibit a peak $\left(\mathrm{kWh} / \mathrm{m}^{2}\right.$ year) for residential and office sectors during 1945-1960, Figs. 7, 8, 9 and 10. Afterwards, in all cases, the values for both investigated countries follow a decreasing trend in energy demand - in Italy higher than in Austria.

Identified differences between the two investigated countries concern mainly historic buildings, building types in the residential sector and the ownership patterns in households.

It has to be stressed that historic buildings are a much higher percentage in Italy's residential sector than in Austria's: 18 and 12\%, respectively (Fig. 1). Also, in the service sector (offices), in Italy the highest share belongs to historic buildings, while in Austria it does not (Fig. 3). Moreover, space heating and domestic hot water during the period before 1945 is halved in Italy compared to Austria, namely, reaching values of 80 and $160 \mathrm{kWh} / \mathrm{m}^{2}$ year respectively (Fig. 7). 
With regard to the different household building types, Austria and Italy differ with regard to all investigated aspects (Fig. 2). In fact, Austria's residential sector is dominated by single-family houses (with a share of over $60 \%$ ), while Italy's share of single family houses is as low as $20 \%$, approximately. Italy's household sector is in fact dominated by multi-family houses (55\% of the total); in Austria these represent only $20 \%$.

Concerning the ownership pattern in the residential sector (Fig. 5), Italy's is characterized by a persistently higher value than Austria with over 90 and almost $60 \%$, respectively.

It would be interesting to find out to what extent building components (e.g., different window types, space heating, domestic hot-water and space-cooling equipment, façade types etc.) and U-values (walls, windows, roofs and ceilings) are similar in the two countries with regard to the various construction spans taken into consideration.

Acknowledgements We would like to convey our deepest appreciation to the Horizon 2020 Hotmaps Project (Grant Agreement number 723677), which provided the funding to carry out the present investigation. We are thankful to Dr. Petra Scudo (EURAC research), who edited the text of the present investigation. Finally, our gratitude goes to Amy Segata (EURAC research) for designing the graphs of this study.

\section{References}

Adnot, J. (2011). Limiting the impact of increasing cooling demand in the European Union: Results from a study on room air-conditioner energy efficiency.

Amtmann, M., \& Altmann-Mavaddat, N. (2014). Eine Typologie Österreichischer Wohngebäude. Österreichische Energieagentur. Vienna: Austrian Energy Agency.

Aprile, M. (2007). European market prospects. Santiago: PolySMART.

Brandschutz, B. (2008). Accessed at: February 8, 2017, from http://www.brandschutz.at/BS/BK_ 08/Adobe/BK_08_62_.pdf.

Benejam, G., Mata, E., Kalagasidis, A., \& Johnsson, F. (2012). Bottom-up characterization of the Spanish building stock for energy assessment and model validation. In Retrofit 2012 Conference. Manchester.

BPIE. (2017). Data hub for energy performance of buildings. Accessed at: December 7, 2017, from https://www.buildingsdata.eu/.

Capehart, B. (2007). Encyclopedia of energy engineering and technology. London, England: CRC Press.

Corrado, V. (2012). National scientific report on the TABULA activities in Italy. Torino: Politecnico di Torino.

Cost-effective. (2017). Accessed at: February 8, 2017, from http://www.cost-effective-renewables. eu/publications.php?type $=$ brochure.

Demuth, C., \& Malloth, T. (2006). Gesetzliche und Wirtschaftliche Rahmenbedingungen des Energieausweises.

EC. (2015). Housing statistics. Accessed at: December 7, 2015, from http://ec.europa.eu/eurostat/ statistics-explained/index.php/Housing_statistics.

EC. (2017a). The 2020 climate and energy package. Accessed at: February 11, 2017, from http:// ec.europa.eu/clima/policies/package/index_en.htm.

EC. (2017b). 2030 Framework for climate and energy policies. Accessed at: February 9, 2017, from http://ec.europa.eu/clima/policies/2030/index_en.htm. 
EC. (2017c). EU action on climate. Accessed at: February 9, 2017, from http://ec.europa.eu/clima/ policies/brief/eu/.

EC. (2017d). EU building stock observatory. Accessed at: February 10, 2017, from https://ec. europa.eu/energy/en/eubuildings.

Economidou, M. (2011). Europe's buildings under the microscope.

Energi, E. (2002). Characterization of heating systems and their market.

Hartl, N. (2010). KeepCool II-Simulationsergebnisse. Vienna: Austrian Energy Agency.

Invert/EE-Lab. (2017). Accessed at: February 16, 2017, from http://www.invert.at/.

ISTAT. (2015). Accessed at: December 7, 2015, from http://dawinci.istat.it/MD/dawinciMD.jsp? $\mathrm{a} 1=\mathrm{u} 0 \mathrm{GG} 0 \mathrm{c} 0 \mathrm{I0}$ anda2 $=\mathrm{mG} 0 \mathrm{Z} 8048 \mathrm{f} 8 \mathrm{andn}=1 \mathrm{UH} 93709 \mathrm{OG}$ andv $=1 \mathrm{UH} 0 \mathrm{MC} 090 \mathrm{O} 00000$.

ISTAT. (2017). Accessed at: December 7, 2017, from http://www.istat.it/en/.

Lazzarin, R., Busato, F., \& Castellotti, F. (2001). L'impatto energetico ed economico dell' isolamento termico degli edifici in Italia.

Mahlknecht, H. (2009). Refurbishment and monitoring of an historical building. Bolzano.

Meijer, F., Itard, L., \& Sunikka-Blank, M. (2009). Comparing European residential building stocks: Performance, renovation and policy opportunities. Building Research and Information, 37(5-6), 533-551.

Melograno, P., \& Pezzutto, S. (2010). Italian country report. IEA ANNEX 34.

Norris, M., \& Shiels, P. (2004). Housing developments in European countries. Dublin: The Housing Unit.

Ostermann, V., Gotzl, G., \& Steckler, P. (2010). Energie der Zukunft.

Öhlinger, C., Dell, G., Egger, C., \& Aufreiter, R. (2010). Beleuchtung, Innovative und effiziente.

Pezzutto, S. (2014). Analysis of the space heating and cooling market in Europe. Ph.D. thesis, Vienna.

Pezzutto, S., Toleikyte, A., \& De Felice, M. (2015). Assessment of the space heating and cooling market in the EU28: A comparison between EU15 and EU13 member states. International Journal of Contemporary Energy, 2, 35-48.

Recknagel, R. (2010). Handbook for heating and air-conditioning technology. Munich: Industry publishing.

Solair. (2008). Market report for small and medium sized solar Air-conditioning appliances.

Statistik Austria. (2017). Accessed at: February 19, 2017, from https://www.statistik.at/web_de/ statistiken/index.html.

TABULA. (2017). Accessed at: February 15, 2017, from http://episcope.eu/iee-project/tabula/.

Vetmeduni Vienna. (2017) Accessed at: February 13, 2017, from http://koeppen-geiger.vu-wien. ac.at/.

Open Access This chapter is licensed under the terms of the Creative Commons Attribution 4.0 International License (http://creativecommons.org/licenses/by/4.0/), which permits use, sharing, adaptation, distribution and reproduction in any medium or format, as long as you give appropriate credit to the original author(s) and the source, provide a link to the Creative Commons license and indicate if changes were made.

The images or other third party material in this chapter are included in the chapter's Creative Commons license, unless indicated otherwise in a credit line to the material. If material is not included in the chapter's Creative Commons license and your intended use is not permitted by statutory regulation or exceeds the permitted use, you will need to obtain permission directly from the copyright holder. 